\title{
Article \\ Exploration of Copper Oxide Nanoneedle Electrosynthesis Applied in the Degradation of Methylene Blue
}

\author{
Diego P. Oyarzún ${ }^{1, *}$, Alejandra Tello ${ }^{1}$, Julio Sánchez ${ }^{2}(0)$ Andrés Boulett ${ }^{2}$, Omar E. Linarez Pérez ${ }^{3}{ }^{\circledR}$, \\ Rudy Martin-Trasanco ${ }^{4}\left(\mathbb{0}\right.$, Guadalupe del C. Pizarro ${ }^{4}$, Marcos Flores ${ }^{5}$ and César Zúñiga ${ }^{6, *}$ \\ 1 Departamento de Química y Biología, Facultad de Ciencias Naturales, Universidad de Atacama, \\ Copayapu 485, Copiapó 1531772, Chile; alejandra.tello@uda.cl \\ 2 Departamento de Ciencias del Ambiente, Facultad de Química y Biología, Universidad de Santiago de \\ Chile (USACH), Santiago 9170022, Chile; julio.sanchez@usach.cl (J.S.); andres.boulett@usach.cl (A.B.) \\ 3 Instituto de Investigaciones en Fisicoquímica de Córdoba (INFIQC), Universidad Nacional de Córdoba, \\ Córdoba 5000, Argentina; olinarez@unc.edu.ar \\ 4 Departamento de Química, Universidad Tecnológica Metropolitana, Avda. Las Palmeras 3360, \\ Santiago 7810000, Chile; ruquim@gmail.com (R.M.-T.); gpizarro@utem.cl (G.d.C.P.) \\ 5 Laboratorio de Superficies y Nanomateriales, Facultad de Física y Ciencias Matemáticas, \\ Universidad de Chile, Beauchef 850, Santiago 8370448, Chile; mflorescarra@ing.uchile.cl \\ 6 Instituto de Ciencias Naturales, Facultad de Medicina Veterinaria y Agronomía, \\ Universidad de Las Americas, Manuel Montt 948, Santiago 7500975, Chile \\ * Correspondence: diego.oyarzun@uda.cl (D.P.O.); czuniga@udla.cl (C.Z.)
}

check for updates

Citation: Oyarzún, D.P.; Tello, A.; Sánchez, J.; Boulett, A.; Linarez Pérez, O.E.; Martin-Trasanco, R.; Pizarro,

G.d.C.; Flores, M.; Zúñiga, C.

Exploration of Copper Oxide

Nanoneedle Electrosynthesis Applied in the Degradation of Methylene Blue. Nanomaterials 2021, 11, 2994. https:// doi.org/10.3390/nano11112994

Academic Editor: Gian Andrea Rizzi

Received: 28 August 2021

Accepted: 2 November 2021

Published: 8 November 2021

Publisher's Note: MDPI stays neutral with regard to jurisdictional claims in published maps and institutional affiliations.

Copyright: (C) 2021 by the authors. Licensee MDPI, Basel, Switzerland. This article is an open access article distributed under the terms and conditions of the Creative Commons Attribution (CC BY) license (https:/ / creativecommons.org/licenses/by/ $4.0 /)$.

\begin{abstract}
In this study, we report a low cost, fast and unexplored electrochemical synthesis strategy of copper oxide nanoneedles films as well as their morphological and chemical characterization. The nanostructured films were prepared using electrochemical anodization in alkaline electrolyte solutions of ethylene glycol, water and fluoride ions. The film morphology shows nanoneedleshaped structures, with lengths up to 1-2 $\mu \mathrm{m}$; meanwhile, high-resolution X-ray photoelectron spectroscopy (HRXPS) and spectroscopy Raman analyses indicate that a mixture of $\mathrm{Cu}(\mathrm{II})$ and $\mathrm{Cu}(\mathrm{I})$ oxides, or only $\mathrm{Cu}(\mathrm{I})$ oxide, is obtained as the percentage of water in the electrolyte solution decreases. A preliminary study was also carried out for the photocatalytic degradation of the methylene blue (MB) dye under irradiation with simulated sunlight in the presence of the nanoneedles obtained, presenting a maximum degradation value of $88 \%$ of $\mathrm{MB}$ and, thus, demonstrating the potential characteristics of the material investigated in the degradation of organic dyes.
\end{abstract}

Keywords: electrosynthesis; $\mathrm{CuO} / \mathrm{Cu}_{2} \mathrm{O}$ nanoneedles; photodegradation

\section{Introduction}

The obtention of the nanostructures of different materials has been a subject of increasing interest in the last decade due to their novel physicochemical properties that allow their application in fields such as medicine, acoustics, optoelectronics, photonics, sensors and electrocatalysts [1-4]. Commonly, nanostructures can be present in various geometries such as wires, rods, points, pores and tubes, among others $[4,5]$.

In addition, nanomaterials produce interesting physical phenomena such as photoluminescence, which make them attractive for the manufacture of electronic devices. The high surface area of these materials could improve the performance of luminescent modules, piezoelectric transducers, semiconductor electrodes, chemical sensors and electrocatalysts $[2,5,6]$. The most studied nanostructures in the last few years correspond to carbon nanotubes [6], titanium dioxide nanotubes [7] and copper oxides nanostructures [8-10]. Among them, copper oxide-based nanomaterials attract attention due to its non-toxic nature, low cost and their low bandgap values of 1.2 to $1.8 \mathrm{eV}$ and 1.8 to $2.5 \mathrm{eV}$ for $\mathrm{CuO}$ and $\mathrm{Cu}_{2} \mathrm{O}$, respectively [11]. Additionally, their conduction and valence bands are close to the water reduction and oxidation potentials, respectively, thus allowing the oxide film 
to produce hydrogen by direct water photolysis without the need for the application of an external potential. These properties make $\mathrm{CuO}$ and $\mathrm{Cu}_{2} \mathrm{O}$ very promising materials for use in converters of solar energy into electrical energy through the design of CuO-based solar cells $[12,13]$ as well as in water photolysis. However, the absorption profile of $\mathrm{CuO}$ is rather weak in most of the visible range [14], which implies that if an electrode formed by a smooth $\mathrm{CuO}$ film is subjected to solar irradiation, a significant part of the photogenerated charge carriers within the material are lost in recombination processes $[15,16]$. Nevertheless, as has been demonstrated for other materials such as $\mathrm{GaP}$ and $\mathrm{SiC}[17,18]$, the use of electrodes composed of nanostructured $\mathrm{CuO}$ or $\mathrm{Cu}_{2} \mathrm{O}$ films, could solve this problem. For nanoporous structures, the charge carriers are photogenerated at a small distance from the semiconductor/electrolyte interface, which, in turn, promotes the separation of charge carriers more efficiently [18], while light absorption is reinforced through dispersion [17].

Currently, several methods for obtaining copper oxide-based nanostructures have been widely reported in the literature. In this, the thermal oxidation of metallic copper at high temperatures stands out [19,20], the growth assisted by templates [21,22], the use of colloidal methods $[23,24]$ and using electrochemical anodization techniques. However, high-temperature processes generally limit the control over the interfacial characteristics of copper oxides thin films, which significantly affect their optical and photoelectrochemical properties [25]. Furthermore, the use of templates and routes of colloidal synthesis are generally characterized by obtaining copper oxides that have a low adhesion on the conductive substrates, which limits their use or integration in electronic devices. Conversely, electrochemical anodization is a surface treatment process that has been successfully used to synthesize a wide variety of nanostructures using various metal substrates, such as titanium, zinc, thallium and copper [26-31], and employing these films in various applications [32-36]. In particular, the preparation of copper oxide films by anodizing the metallic copper used as a substrate is also the source of the copper ions that are subsequently oxidized by the presence of water molecules composing the electrolyte solution and the voltage applied to the medium [37]. In this context, various morphologies of anodized copper oxide nanostructures, such as nanoneedles, nanorods, nanopores, nanowires and nanoparticles, have been reported [38]. Among these reported morphologies, nanowires stand out due to their high surface area, which increases the reactivity area of the material $[13,31]$; this offers potential advantages for their integration in electronic devices since they have a much more efficient electrical contact with the metal [13,31], for biomaterial applications or as a non-toxic photocatalyst, low cost and easy to obtain, for the photodegradation of organic molecules, such as dyes and wastewater pollutants [13,31]. Although it has been reported to obtain copper oxide nanoneedles by anodization using an electrolytic medium composed of $\mathrm{KOH}[31,39-41]$, in no case has an ethylene glycol-based electrolyte medium been used in conjunction with fluoride ions [11,31,39-43]. Tello et al., during 2021, have reported that an electrolytic medium based on the mentioned chemical compounds benefit the morphological order of anodized nanostructures, due to the high viscosity of the solvent and the interference generated by the fluoride ions on the surface of the copper layer during anodization [13,31]. In addition, only one of these studies has used the anodization technique without subsequent heat treatment to dehydrate the $\mathrm{Cu}(\mathrm{OH})_{2}$ nanoneedles to $\mathrm{CuO}$ [41].

Effluents from the textile, plastic and paper industries contain colorants such as methylene blue (MB) [44], which is a well-known toxic, mutagenic and carcinogenic dye. For this reason, its elimination from wastewater is essential to minimize the effects on aquatic life and the associated problems. In this regard, many conventional methods have been developed for the removal of dyes from wastewater, such as ozonation, liquid-liquid extraction, photodegradation, precipitation, membrane filtration, ion exchange, coagulation and adsorption [45]. However, the advantage of photodegradation compared to these techniques and others used to degrade dyes, such as degradation by algae, enzymes, metal nanoparticles and electrochemistry, is that solar energy is used to produce the reaction that will degrade the dye, which significantly reduces operating costs [46]. To perform the 
photocatalytic process, a semiconductor material with bandgap energy values $\mathrm{Eg}<4 \mathrm{eV}$ is used, which favors the excitation of its valence electrons (VB) toward the conduction band (CB) by means of a light energy source [47].

In this work, we report an unexplored electrochemical strategy synthesis of $\mathrm{CuO} / \mathrm{Cu}_{2} \mathrm{O}$ nanoneedles films as well as their chemical and morphological characterization. The anodization was performed in alkaline electrolyte mixtures of ethylene glycol, water and fluoride ions. The film characterization was performed by means of Raman spectroscopy, field emission scanning electron microscopy (FESEM), atomic force microscopy (AFM), transmission electron microscopy (TEM) and HRXPS. Additionally, the previously obtained copper oxide nanostructures were used to perform a study of the photocatalytic degradation of MB in aqueous solution.

\section{Materials and Methods}

Copper anodization was performed in an electrochemical cell with a two-electrode configuration. The anode electrodes consisted of polycrystalline copper foils (Sigma Aldrich (Spruce Street, LA, USA), 99.99\% purity) of $250 \mu \mathrm{m}$ in thickness $\left(0.5 \mathrm{~cm}^{2}\right.$ of exposed geometric area) mounted in Teflon holders. A 0.5-centimeter-thick carbon sponge of $3.0 \times 3.5 \mathrm{~cm}^{2}$ was used as a cathode electrode. Prior to anodization, the samples were mechanically polished using a 0.05-micrometer alumina aqueous suspension and then, degreased by sonication in a 50:50\% acetone/ethanol mixture for $15 \mathrm{~min}$. After cleaning, the foils were rinsed with deionized water and dried under $\mathrm{N}_{2}$ flux. The anodization was carried out at $5{ }^{\circ} \mathrm{C}$ by applying a voltage of 10 using a high-power source, for $180 \mathrm{~s}$. The electrolyte solution was prepared from analytical grade reagents and was based on ethylene glycol $+[0.5 ; 10] \%$ v / v water, $0.1 \mathrm{M} \mathrm{NaOH}$ or $0.1 \mathrm{M} \mathrm{KOH}$ and $0.1 \% w / v \mathrm{NH}_{4} \mathrm{~F}$ Merck (Darmstadt, Germany).

The morphology features of the nanostructured layers were characterized by FE-SEM using a Carl Zeiss Sigma microscope (Oberkochen, Germany). Raman experiments were performed ex situ (in air) using a Horiba LabRAM HR spectrometer (Sunnyvale, CA, USA), employing a He/Ne laser (632.8 nm wavelength). Using an XPS-Auger Perkin Elmer Model PHI 1257 spectrometer (Waltham, MA, USA) was employed to determine the chemical composition of samples, by means of HRXPS and using the method described previously [48-50]. For AFM measurements, a Nanonics Multi View MV1000 was employed using $\mathrm{n}$-type silicon cantilevers (tip radius $\approx 20 \mathrm{~nm} ; \mathrm{f}=39.4 \mathrm{kHz} ; \mathrm{Q}=1576$ ) for the intermittent mode. TEM was performed using LEO 1420VP equipment (Oberkochen, Germany). Prior to the TEM measurements, a dispersion of copper oxide nanoneedles was obtained by sonication during $15 \mathrm{~min}$ of the oxide films in isopropyl alcohol. The analysis of images was performed with the image processing software Gwyddion 2.37. The photocatalytic activity was carried out using a $1000 \mathrm{~W}$ Xe/ $\mathrm{Hg}$ lamp (Oriel 6295) as a simulation of a source of sunlight. In order to avoid the overheating of the MB solution, the infrared radiation was eliminated through a water filter. The copper oxide nanoneedles were immersed in a quartz cell containing $15 \mathrm{~mL}$ of a $2.5 \mathrm{mM}$ dye solution. In order to reach the adsorption equilibrium, the samples were held one hour in the dark with permanent air bubbling for also assuring dissolved oxygen saturation at the beginning of the photocatalytic degradation process. The experiments were performed in triplicate for $120 \mathrm{~min}$, and the dye concentration measurements were taken at $\lambda_{\max }=660 \mathrm{~nm}$ every $30 \mathrm{~min}$ in comparison to a previously recorded calibration curve.

\section{Results and Discussion}

Figure $1 \mathrm{a}$ shows the $\mathrm{j} / \mathrm{t}$ potentiostatic profile applying a constant potential of $10 \mathrm{~V}$ during $3 \mathrm{~min}$ in a $0.1 \mathrm{M} \mathrm{KOH}+10 \% v / v \mathrm{H}_{2} \mathrm{O}+0.1 \% w / v \mathrm{NH}_{4} \mathrm{~F}$ dissolved in ethylene glycol solution. After an abrupt initial current density increase, the current profile shows a rapid diminution in current density within the first milliseconds and then a slight variation from around 5 to $3 \mathrm{~mA} / \mathrm{cm}^{2}$ for the subsequent $3 \mathrm{~min}$ due to the passivation of the copper surface [51]. The presence of ethylene glycol and hydroxyl ions in the electrolytic medium 
may stabilize the current density during the anodization due to its density and polarity as well as the alkaline $\mathrm{pH}$ employed [13,31]. On the other hand, the Raman spectrum for the anodized copper foil (see Figure 1b) shows typical intense signals at around 284 and $335 \mathrm{~cm}^{-1}$, indicating the presence of $\mathrm{CuO}$ species [52,53]. Additionally, signals at 150, 545.6 and $625.6 \mathrm{~cm}^{-1}$, which are characteristic of $\mathrm{Cu}_{2} \mathrm{O}$, are obtained. It should be mentioned that these signals are less intense than those for $\mathrm{CuO}$, which would indicate a low presence of $\mathrm{Cu}$ (I) on the surface of the copper foil [52].

(a)

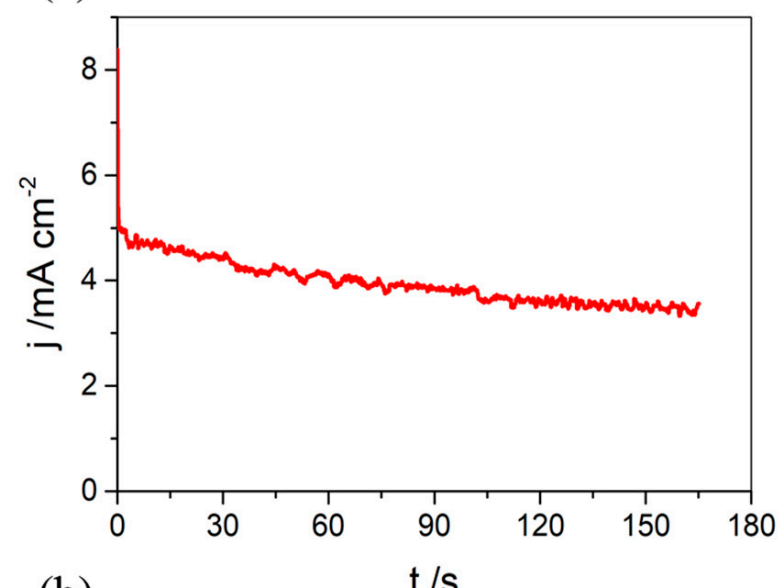

(b)

\section{$\mathrm{t} / \mathrm{s}$}

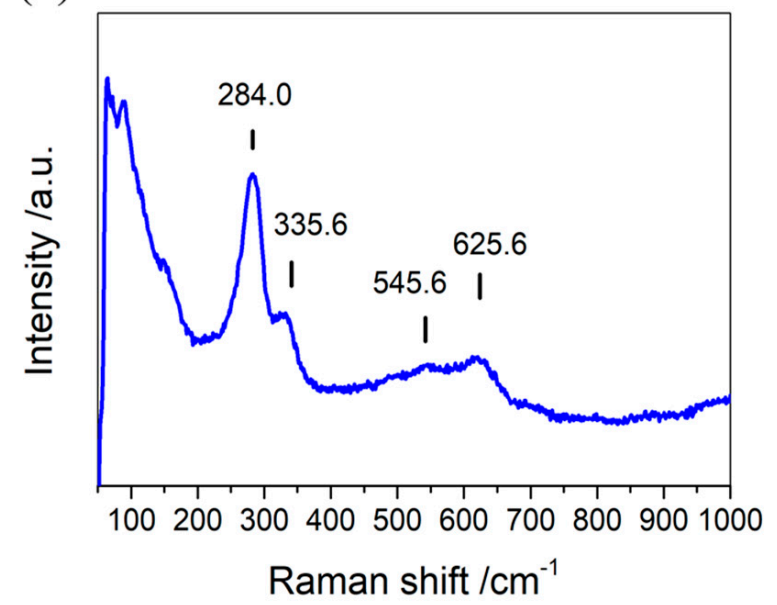

Figure 1. $\mathrm{j} / \mathrm{t}$ potentiostatic profile (a) and Raman spectrum $(\mathbf{b})$ for $\mathrm{Cu}$ foils anodized at $5{ }^{\circ} \mathrm{C}$ applying constant potential of $10 \mathrm{~V}$ during $3 \mathrm{~min}$ in a $0.1 \mathrm{M} \mathrm{KOH}+10 \% v / v \mathrm{H}_{2} \mathrm{O}+0.1 \% w / v \mathrm{NH}_{4} \mathrm{~F}$ electrolyte and dissolved in ethylene glycol.

Additionally, the chemical analysis performed using XPS measurements indicates the presence of a $\mathrm{Cu}_{2} \mathrm{O} / \mathrm{CuO}$ oxides mixture in the anodized surfaces $[37,54]$. The high resolution $\mathrm{Cu} 2 \mathrm{p}$ spectrum (see Figure 2a) shows important contributions at a binding of 932.2 and $933.9 \mathrm{eV}$; these signals are attributed to $\mathrm{Cu}+\mathrm{Cu}_{2} \mathrm{O}, \mathrm{CuO}$ and [49], for the case of the $\mathrm{Cu}$-Auger signal, the $\mathrm{Cu}+\mathrm{CuO}$ and $\mathrm{Cu}_{2} \mathrm{O}$ contributions are identified at binding energy of 567.0 and $569.3 \mathrm{eV}$, respectively (see Figure $2 \mathrm{~b}$ ). Additionally, high resolution O1s spectrum (see Figure 2c) evidences the presence of both $\mathrm{CuO}$ and $\mathrm{Cu}_{2} \mathrm{O}$ oxides as well as hydrated species in the sample, which are in agreement with the above showed Raman results. Such hydrated species are also identified in the Cu2p main signal at $936.2 \mathrm{eV}$ in binding energy. 
(a)

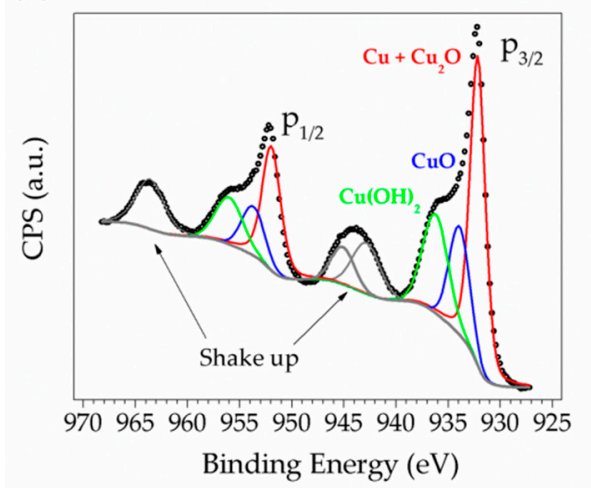

(b)

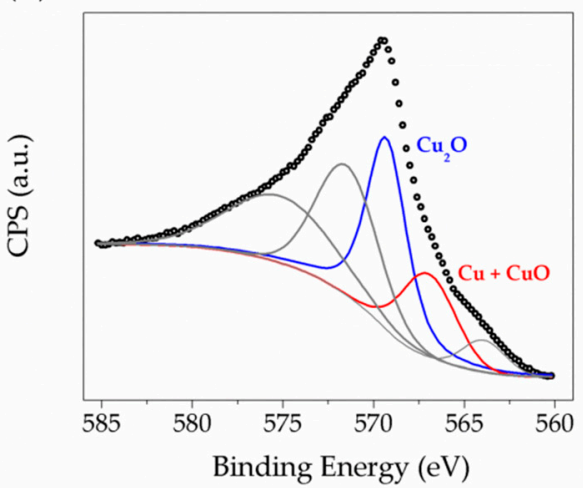

(c)

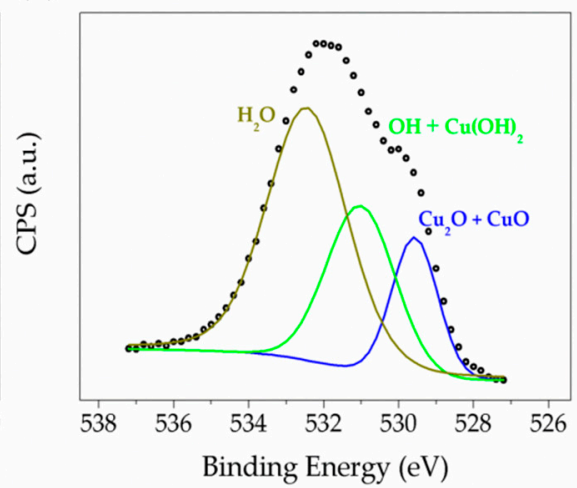

Figure 2. HRXPS spectra of (a) Cu-2p, (b) Cu-Auger and (c) $\mathrm{O}-1 \mathrm{~s}$, for $\mathrm{Cu}$ foils anodized at $5{ }^{\circ} \mathrm{C}$ applying constant potential of $10 \mathrm{~V}$ during $3 \mathrm{~min}$ in a $0.1 \mathrm{M} \mathrm{KOH}+10 \% v / v \mathrm{H}_{2} \mathrm{O}$ electrolyte $+0.1 \% w / v \mathrm{NH}_{4} \mathrm{~F}$ and dissolved in ethylene glycol.

Table 1 shows a summary of the results obtained from the XPS measurements; from these values and by using the formulation of Platzman, we estimate the percent for each copper oxidation state [50]. It can be observed that the formation of $\mathrm{Cu}(\mathrm{I})$ species predominates in electrode surfaces $(46 \%)$ after the synthesis process. However, the minor proportion of oxidized $\mathrm{Cu}$ (II) species (22\%) may be attributed to an excessive amount of $\mathrm{H}_{2} \mathrm{O}$ in the electrolytic bath as well as the high voltage applied during the anodization, given also a high amount of hydrated species, $25 \%$. A small amount of metallic copper $(6 \%)$ was identified. From the values of this table, the alpha parameter can be determined, which is independent of charge effects, alpha $=\mathrm{KE}(\mathrm{LMM})+\mathrm{BE}(2 \mathrm{p})=917.3 \mathrm{eV}+932.2 \mathrm{eV}=1849.5 \mathrm{eV}$ and $917.3 \mathrm{eV}+933.9 \mathrm{eV}=1851.2 \mathrm{eV}$. These values are in agree with the literature [55], and in the Wagner plot, can be labeled as $\mathrm{Cu}_{2} \mathrm{O}$ and $\mathrm{CuO}$, respectively.

Table 1. Cu-2p and O-1s data table of XPS spectra, for $\mathrm{Cu}$ foils anodized at $5{ }^{\circ} \mathrm{C}$ applying a constant potential of $10 \mathrm{~V}$ during $3 \mathrm{~min}$ in a $0.1 \mathrm{M} \mathrm{KOH}+10 \% v / v \mathrm{H}_{2} \mathrm{O}$ electrolyte and dissolved in ethylene glycol.

\begin{tabular}{|c|c|c|c|}
\hline \multicolumn{4}{|c|}{$\mathrm{Cu}-2 \mathrm{p}_{3 / 2}$} \\
\hline Chemical Composition & $\mathrm{eV}$ & Area & $\%$ At Conc \\
\hline $\mathrm{Cu}+\mathrm{Cu}_{2} \mathrm{O}$ & 932.2 & 251,548 & 42 \\
\hline $\mathrm{CuO}$ & 933.9 & 104,503 & 18 \\
\hline $\mathrm{Cu}(\mathrm{OH})_{2}$ & 936.2 & 120,911 & 20 \\
\hline \multicolumn{4}{|c|}{ Cu-Auger } \\
\hline Chemical Composition & eV & Area & $\%$ At Conc \\
\hline $\mathrm{Cu}+\mathrm{CuO}$ & 567.0 & 48,456 & 14 \\
\hline $\mathrm{Cu}_{2} \mathrm{O}$ & 569.3 & 103,025 & 31 \\
\hline \multicolumn{4}{|c|}{ O-1s } \\
\hline Chemical Composition & $\mathrm{eV}$ & Area & $\%$ At Conc \\
\hline $\mathrm{OH}+\mathrm{Cu}(\mathrm{OH})_{2}$ & 529.6 & 17,556 & 16 \\
\hline $\mathrm{Cu}_{2} \mathrm{O}+\mathrm{CuO}$ & 531.0 & 30,615 & 28 \\
\hline $\mathrm{H}_{2} \mathrm{O}$ & 532.5 & 61,589 & 56 \\
\hline
\end{tabular}

In order to study the morphology of the obtained films, several microcopy techniques were employed. Figure $3 \mathrm{a}, \mathrm{b}$ show a top view FESEM micrography of the $\mathrm{CuO} / \mathrm{Cu}_{2} \mathrm{O}$ film obtained, which shows a highly homogeneous self-assembled nanoneedles array. The main length of the needles is between ca. 1 and $2 \mu \mathrm{m}$. A more detailed study morphology was performed using TEM measurements of a $\mathrm{CuO} / \mathrm{Cu}_{2} \mathrm{O}$ nanoneedles dispersion (see 
Figure 3c). Long and thin structures with lengths ranging between 200 and $500 \mathrm{~nm}$ corresponding to the entire and fragmented nanoneedles are observed (see Figure $3 \mathrm{c}$ and inset). In addition, Figure 3d shows a 3D AFM image for the anodic films obtained, showing a similar morphology as those obtained from FESEM (see Figure 3a,b).

(a)

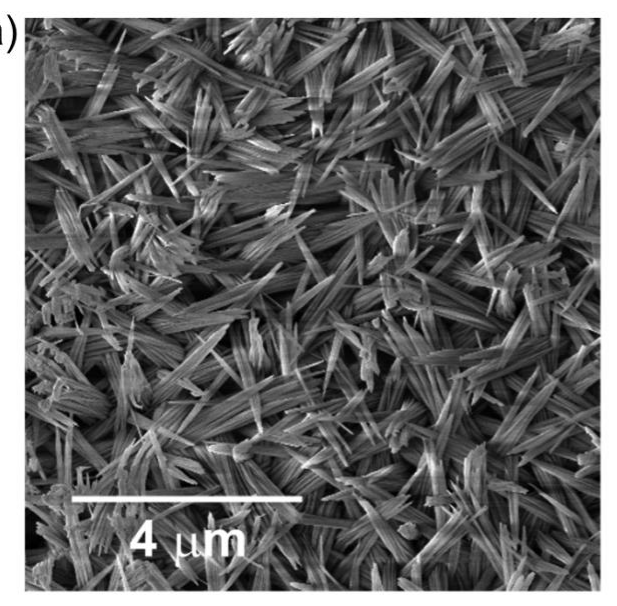

(c)

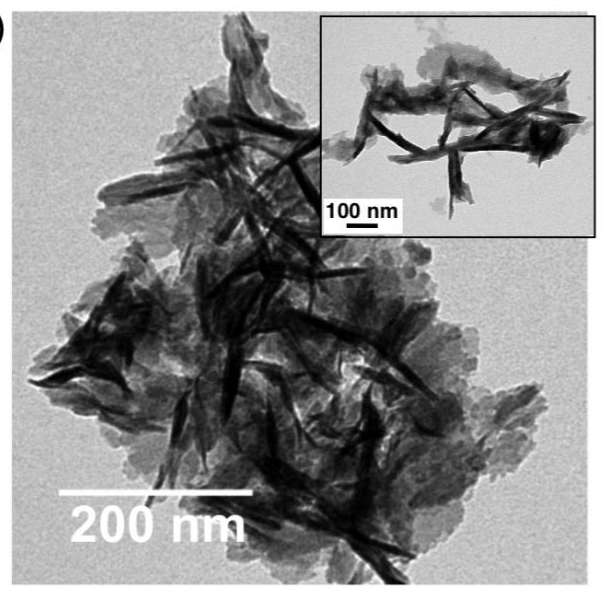

(b)

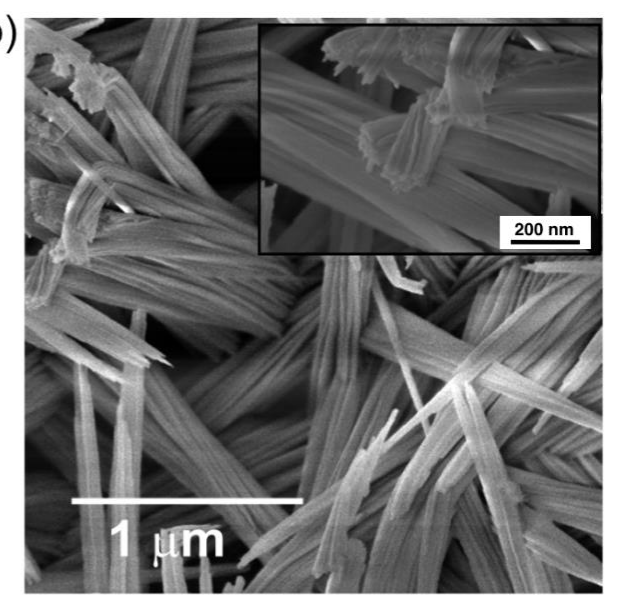

(d)

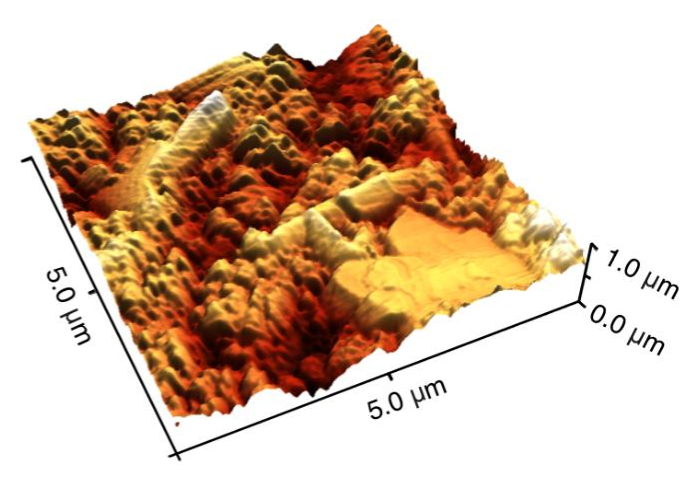

Figure 3. Morphology of anodic $\mathrm{CuO} / \mathrm{Cu}_{2} \mathrm{O}$ nanoneedles obtained for $\mathrm{Cu}$ foils anodized at $5{ }^{\circ} \mathrm{C}$ applying a constant potential of $10 \mathrm{~V}$ during $3 \mathrm{~min}$ in a $0.1 \mathrm{M} \mathrm{KOH}+10 \% v / v \mathrm{H}_{2} \mathrm{O}$ electrolyte $+0.1 \% w / v \mathrm{NH}_{4} \mathrm{~F}$ and dissolved in ethylene glycol film obtained by means of (a) and (b) FESEM, (c) TEM and (d) AFM.

On the other hand, by decreasing the percentage of water in the electrolyte solution below $10 \% v / v$ during anodization, $\mathrm{CuO} / \mathrm{Cu}_{2} \mathrm{O}$ or $\mathrm{Cu}_{2} \mathrm{O}$ nanoneedles are obtained on a flake surface and the nanoneedles have a smaller average length as the percentage of water decreases. The Raman spectra of the nanoneedles obtained using $5 \% v / v$ water in their synthesis show signals at $146.2,540.3$ and $621.4 \mathrm{~cm}^{-1}$, which are characteristic of $\mathrm{Cu}_{2} \mathrm{O}$, together with the signals at 286.7 and $345.5 \mathrm{~cm}^{-1}$, which further indicate the presence of $\mathrm{CuO}$ in the sample (see Figure 4) [37,52,53,56], whereas, when further reducing the percentage of water in the synthesis, only characteristic signals for the presence of $\mathrm{Cu}_{2} \mathrm{O}$ in the samples are observed [57]. The formation of these nanostructures is explained by the basic medium in which it is found, since the presence of $\mathrm{OH}^{-}, \mathrm{H}_{2} \mathrm{O}$ and ethylene glycol ions tend to the formation of $\mathrm{CuO}$ nanostructures from metallic copper (Equation (1)) [38,40,56]. Moreover, the presence of fluoride ions tends to the redissolution of the $\mathrm{CuO}$ previously obtained and the subsequent formation of $\mathrm{Cu}_{2} \mathrm{O}$ (Equations (2) and (3)). Finally, a higher presence of hydroxyl ions when using higher percentages of water again produces $\mathrm{CuO}$ from the previously formed $\mathrm{Cu}_{2} \mathrm{O}$, obtaining a mixture of copper (I) and (II) oxides (Equation (4)) [40,50]. On the other hand, the FESEM images obtained show a highly rough surface made up of a thin film of nanoneedles with diameters apparently below $100 \mathrm{~nm}$. The homogeneity 
and chemical composition of the synthesized material varies according to the increase in the quantity of water in the electrolytic medium, showing an apparent length diminishing as the water content augments (see Figure 4I-IV). Figure 5 shows a summary diagram of the morphology, diameter and chemical composition of the copper oxide nanostructures obtained as a function of the percentage of water used in their respective anodizations.

$$
\begin{gathered}
\mathrm{Cu}_{(\mathrm{s})}+2 \mathrm{OH}^{-}{ }_{(\mathrm{aq})} \rightarrow \mathrm{CuO}_{(\mathrm{s})}+\mathrm{H}_{2} \mathrm{O}_{(\mathrm{l})}+2 \mathrm{e}^{-} \\
\mathrm{Cu}_{(\mathrm{sup})}+\mathrm{F}^{-}{ }_{(\mathrm{aq})} \rightarrow \mathrm{Cu}-\mathrm{F}_{(\mathrm{ad})}+\mathrm{e}^{-} \\
2 \mathrm{Cu}-\mathrm{F}_{(\mathrm{ad})}+2 \mathrm{OH}^{-}{ }_{(\mathrm{aq})} \rightarrow \mathrm{Cu}_{2} \mathrm{O}_{(\mathrm{s})}+\mathrm{H}_{2} \mathrm{O}_{(\mathrm{l})}+2 \mathrm{~F}^{-} \\
\mathrm{Cu}_{2} \mathrm{O}_{(\mathrm{s})}+2 \mathrm{OH}^{-}{ }_{(\mathrm{aq})} \rightarrow 2 \mathrm{CuO}_{(\mathrm{s})}+\mathrm{H}_{2} \mathrm{O}_{(\mathrm{l})}+2 \mathrm{e}^{-}
\end{gathered}
$$
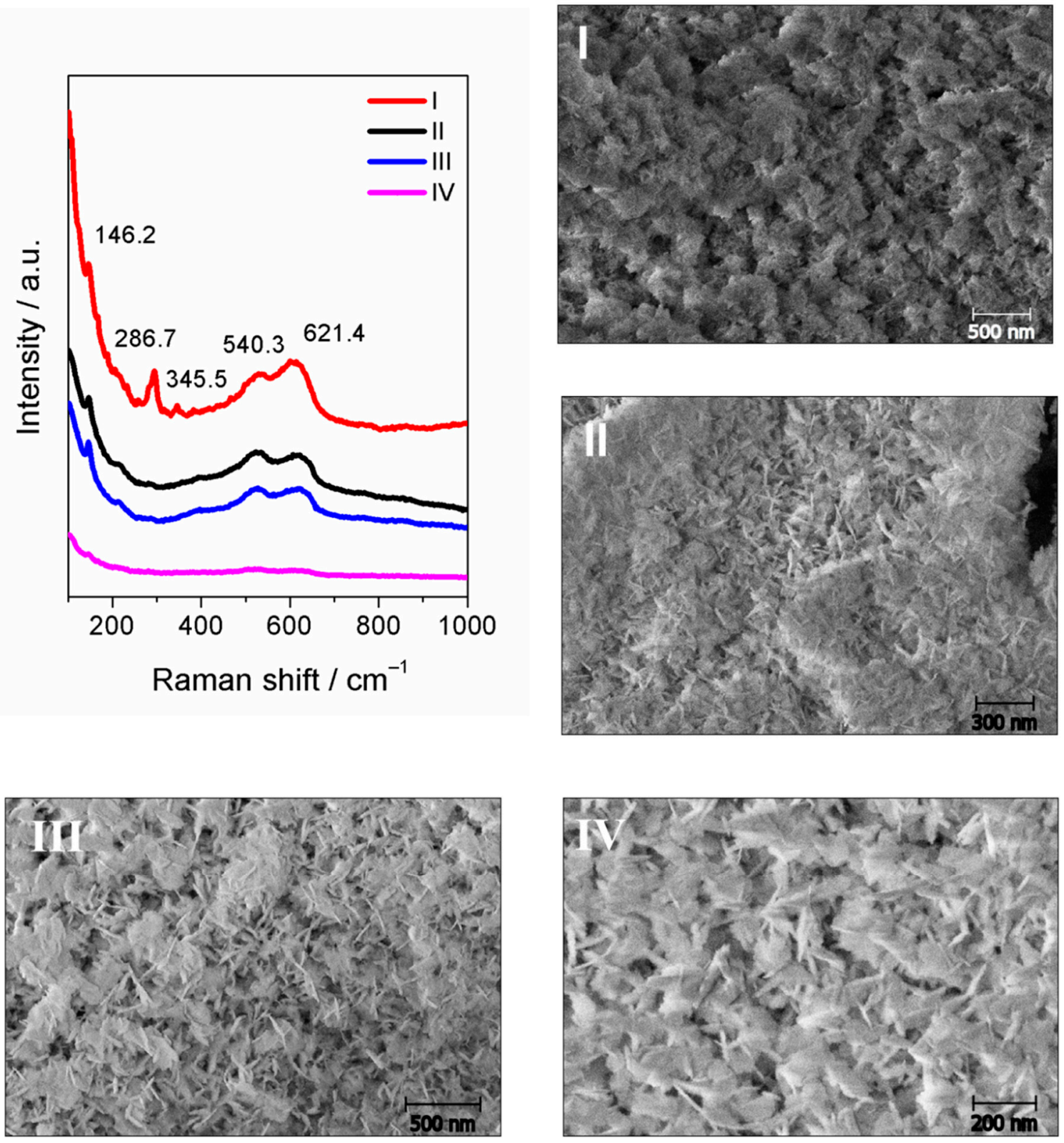

Figure 4. Raman spectra and FESEM images (I-IV) of copper oxides nanoneedles synthesized by electrochemical anodization at $10 \mathrm{~V}$, for $3 \mathrm{~min}$ and $5{ }^{\circ} \mathrm{C}$, using $\mathrm{X} \% v / v \mathrm{H}_{2} \mathrm{O}(\mathrm{I}=5.0, \mathrm{II}=1.5, \mathrm{III}=1.0, \mathrm{IV}=0.5)+0.1 \mathrm{M} \mathrm{NaOH}+0.1 \% w / v \mathrm{NH} \mathrm{F}^{\mathrm{F}}$ dissolved in ethylene glycol. 
Based on the discussion of the figures above, it can be deduced that during anodization, a layer of $\mathrm{Cu}_{2} \mathrm{O}$ flakes is generated on the surface of the copper foil, and $\mathrm{Cu}_{2} \mathrm{O}$ or $\mathrm{Cu}_{2} \mathrm{O} / \mathrm{CuO}$ nanowires start to emerge on them, depending on the percentage of water used in the synthesis (see Figure 5). This interface, generated between the flakes adhered to the anode surface and the nanowires, allows the nanowires to reach longer lengths as the percentage of water in the synthesis increases [31,37,39-41].

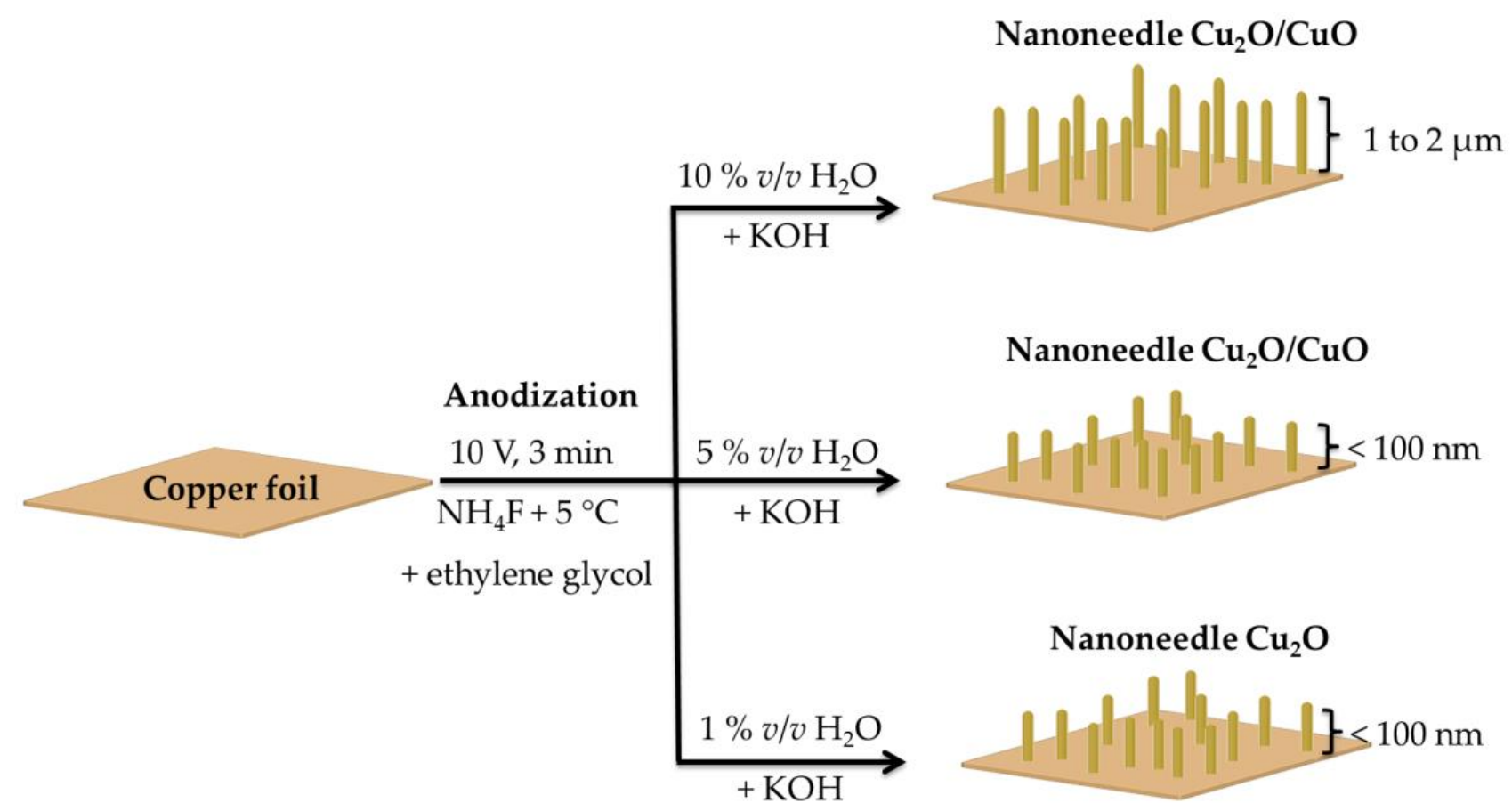

Figure 5. Schematic diagram of the morphology, diameter and chemical composition of the copper oxide nanostructures obtained as a function of the percentage of water used in their respective anodizations.

The photocatalytic activity was evaluated by performing a preliminary study (without adjusting the conditions, such as the amount of xerogel, solution $\mathrm{pH}$, dye concentration and volume) on the degradation of the $\mathrm{MB}$ dye, evaluating as a function of the simulated solar irradiation time of $\mathrm{CuO} / \mathrm{Cu}_{2} \mathrm{O}$ nanoneedles obtained by anodization with 10 or $3.0 \% v / v$ water in the electrolyte solution during their synthesis, and $\mathrm{Cu}_{2} \mathrm{O}$ nanoneedles obtained by anodization with $1.0 \%$ water in the electrolyte solution during their synthesis (see Figure 6a). It is observed that the photocatalytic activity of the $\mathrm{CuO} / \mathrm{Cu}_{2} \mathrm{O}$ nanoneedles photocatalysts reaches maximum values of 88 and $82 \%$ for the syntheses with 10 and $5 \%$ water, respectively; while, for the $\mathrm{Cu}_{2} \mathrm{O}$ nanoneedles obtained with $1 \%$ water, in the synthesis it reaches a maximum value of $74 \%$, which indicates that the photocatalytic activity of the materials decreases as a function of the percentage of water used during the synthesis of each photocatalyst, that is, the photocatalytic activity of $\mathrm{CuO} / \mathrm{Cu}_{2} \mathrm{O}$ nanoneedles is higher than that of $\mathrm{Cu}_{2} \mathrm{O}$. This is attributed to the chemical nature of the photocatalyst, since upon irradiation with solar energy (Equation (5)), the electrons $\left(\mathrm{e}^{-}\right.$) and holes $\left(\mathrm{h}^{+}\right)$generated in the $\mathrm{CuO} / \mathrm{Cu}_{2} \mathrm{O}$ heterojunction network have a longer lifetime than those of a $\mathrm{Cu}_{2} \mathrm{O}$ photocatalyst, because the $\mathrm{VB}$ and $\mathrm{CB}$ of $\mathrm{CuO}$ have a lower energy level than the $\mathrm{VB}$ and $\mathrm{CB}$ of $\mathrm{Cu}_{2} \mathrm{O}$, respectively, generating a transfer of photoinduced $\mathrm{e}^{-}$from the $\mathrm{CB}$ of $\mathrm{Cu}_{2} \mathrm{O}$ to that of $\mathrm{CuO}$ and $\mathrm{h}^{+}$from the $\mathrm{VB}$ of $\mathrm{CuO}$ to that $\mathrm{Cu}_{2} \mathrm{O}$ and, in turn, increasing the lifetime of the promoted electrons and the photocatalytic activity of the material (see Figure $6 \mathrm{~b}$ ) [11]. Subsequently, these $\mathrm{e}^{-} / \mathrm{h}^{+}$pairs can react with water molecules in the vicinity of the semiconductor, generating reductive reactions between the promoted electrons and the $\mathrm{O}_{2}$ in the water, producing superoxide $\left(\mathrm{O}_{2}{ }^{-} \bullet\right)$ (Equations (6) and (7)) and hydroxyl $(\mathrm{OH} \bullet$ ) radicals (Equation (8)), and oxidative reactions between the holes formed and the $\mathrm{OH}^{-}$coming from the water (Equation (9)) or with the 
water molecules themselves (Equation (10)), also producing hydroxyl (OH•) radicals [11]. In addition, it has been reported in the scientific literature that the Eg values for $\mathrm{Cu}_{2} \mathrm{O} / \mathrm{CuO}$ nanostructures estimated from their UV-Vis absorbance spectra are between 1.5 and $1.9 \mathrm{eV}$ [11], while, for $\mathrm{Cu}_{2} \mathrm{O}$, it reaches values of between 1.8 and $2.5 \mathrm{eV}$, i.e., a higher amount of energy is needed to photoinduce $\mathrm{e}^{-}$from VB to CB in a semiconductor composed of $\mathrm{Cu}_{2} \mathrm{O}$ than in a semiconductor composed of a mixture of copper oxides, which also justifies the lower photocatalytic activity obtained for the $\mathrm{Cu}_{2} \mathrm{O}$ nanoneedles [11].

On the other hand, when comparing the photocatalytic activity at lower irradiation times, it is observed that the percentage of $\mathrm{MB}$ degradation for the $\mathrm{Cu}_{2} \mathrm{O} / \mathrm{CuO}$ nanoneedles obtained with $10 \%$ water during the synthesis is lower than those obtained with $5 \%$ water during the synthesis, which is attributed to the fact that the photoinduced $\mathrm{e}^{-}$and $\mathrm{h}^{+}$ generated in the $\mathrm{Cu}_{2} \mathrm{O} / \mathrm{CuO}$ nanoneedles obtained with $10 \%$ water have a longer lifetime, but need a longer interaction time between the photocatalyst and the dye to present a significantly higher photocatalytic activity [11].

$$
\begin{gathered}
\text { Semiconductor }+\mathrm{hv}>\mathrm{Eg} \rightarrow \mathrm{e}^{-}{ }_{(\mathrm{VB})}+\mathrm{h}^{+}{ }_{(\mathrm{CB})} \\
\mathrm{e}^{-}+\mathrm{O}_{2} \rightarrow \mathrm{O}_{2}^{-} \bullet \\
2 \mathrm{O}_{2}^{-} \bullet+2 \mathrm{H}^{+} \rightarrow \mathrm{H}_{2} \mathrm{O}_{2}+\mathrm{O}_{2} \\
\mathrm{H}_{2} \mathrm{O}_{2}+\mathrm{e}^{-}+\mathrm{H}^{+} \rightarrow \mathrm{H}_{2} \mathrm{O}+\mathrm{OH} \bullet \\
\mathrm{h}^{+}+\mathrm{OH}^{-} \rightarrow \mathrm{OH} \bullet \\
\mathrm{h}^{+}+\mathrm{H}_{2} \mathrm{O} \rightarrow \mathrm{H}^{+}+\mathrm{OH} \bullet
\end{gathered}
$$

The structural decomposition of MB is mainly caused by the effect of the hydroxyl radicals generated between the reactions of the water molecules with the $\mathrm{e}^{-}$and mainly the $\mathrm{h}^{+}$ generated in the photocatalyst. It has been reported that the first thing that is detached from the MB molecules during degradation are the methyl groups attached to the amine group; subsequently, several unstable intermediates are formed with minimum existence periods, until obtaining compounds less complex than the dye, such as $\mathrm{SO}_{4}{ }^{2-}, \mathrm{NO}_{3}{ }^{-}, \mathrm{Cl}^{-}, \mathrm{NH}_{4}{ }^{+}$ and mainly $\mathrm{H}_{2} \mathrm{O}$ and $\mathrm{CO}_{2}$ [58]. The level of the highest energy occupied molecular orbital (HOMO) and the lowest energy unoccupied molecular orbital (LUMO) of MB have values of 4.25 and $6.11 \mathrm{eV}$, respectively. $\mathrm{MB}$, when irradiated with an energy higher than $6.11 \mathrm{eV}$ $\left(1.48 \times 10^{15} \mathrm{~Hz}\right)$, causes an electron to be promoted from the HOMO to the LUMO, leading to the breaking of a bond and the subsequent degradation of MB [59]. The simulated sunlight used fulfills this characteristic, as it is mainly composed of infrared, visible and, to a lesser extent, UV light $\left(7.5 \times 10^{14}-3 \times 10^{15} \mathrm{~Hz}\right)$, producing a synergistic effect between the degradation of MB due to the UV light portion (approximately 5\% of the sunlight) and the free radicals generated in the semiconductor during photodegradation [58]. In repeated photocatalytic degradation tests, the recycling stability of the copper oxide nanoneedles was evaluated for the synthesized system under the experimental conditions of $10 \mathrm{~V}, 3 \mathrm{~min}$, $10 \% \mathrm{H}_{2} \mathrm{O}$ (see Figure $6 \mathrm{c}$ ). After each repeated cycle, the $\mathrm{Cu}_{2} \mathrm{O} / \mathrm{CuO}$ nanostructures were filtered, washed rigorously several times and dried. After five cycles of experiments, the photocatalytic activity of the material continues to show a high degradation index, demonstrating the high stability of this type of copper oxides nanostructures over time, in addition to having all the attributes of reusable materials, to promote sustainable development. 
(a)

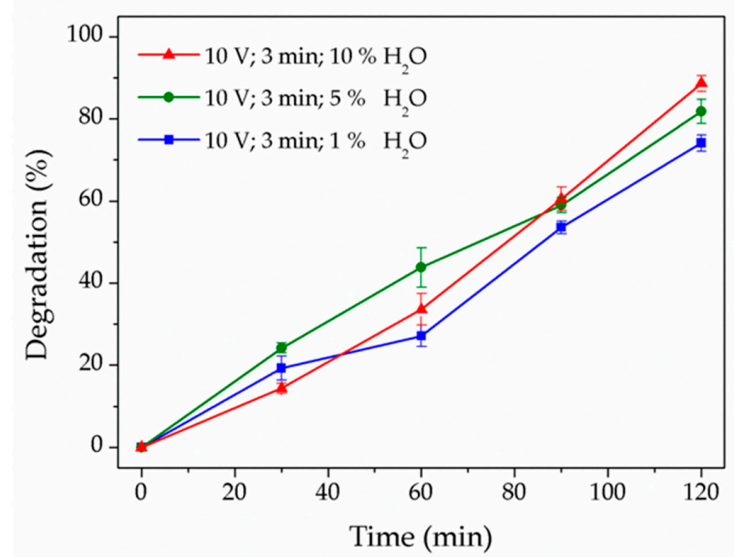

(b)

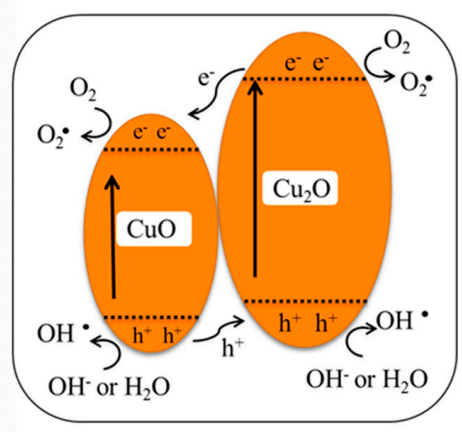

(c)

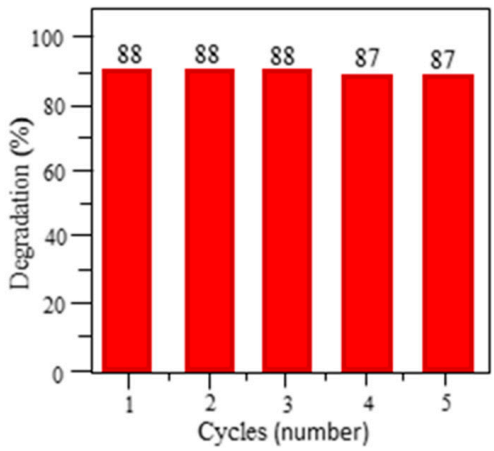

Figure 6. (a) Percentage of methylene blue $\left(2.5 \mathrm{mM}\right.$ of $\mathrm{MB}$ with $0.001 \mathrm{~g} / 15 \mathrm{~mL}$ of $\mathrm{CuO} / \mathrm{Cu}_{2} \mathrm{O}$ nanoneedles) degradation as a function of illumination time for different copper oxides nanostructures. (b) photodegradation diagram of $\mathrm{MB}$ with $\mathrm{CuO} / \mathrm{Cu}_{2} \mathrm{O}$ and (c) recycling histogram after five cycles of MB degradation.

As mentioned above, in this study a maximum photocatalytic activity of $86 \%$ was achieved in the degradation of $\mathrm{MB}$ using $\mathrm{Cu}_{2} \mathrm{O} / \mathrm{CuO}$ nanowires and solar energy. This obtained value is lower than the values previously reported in the scientific literature for various photocatalysts composed of mixtures of metal oxides photo exposed with visible light (see Table 2) [60-63]. These are attributed to the formation of a heterojunction network between the VB and CB of the metal oxides of different chemical nature, which benefits the lifetime of the photogenerated reactive species [60-63]. Specifically, Li et al., in 2021, reported the highest photocatalytic activity for MB degradation (99\%) using a $\mathrm{Cu}_{2} \mathrm{O} / \mathrm{Ag} / \mathrm{TiO}_{2} /$ polyacrylonitrile nanofiber composite system; however, when studying the material composed only of $\mathrm{Cu}_{2} \mathrm{O}$ nanoparticles stabilized on polyacrylonitrile nanofibers $\left(\mathrm{Cu}_{2} \mathrm{O} / \mathrm{NFs}-\mathrm{PAN}\right)$, a photocatalytic activity of only $60 \%$ was reported, which is lower than those obtained in this study [63]. While comparing the materials studied in this research with the standard $\mathrm{P} 25 \mathrm{TiO}_{2}$ degussa applied in the photodegradation of $\mathrm{MB}$, higher or equal photocatalytic activity values were obtained in the preliminary study carried out with anodized $\mathrm{Cu}_{2} \mathrm{O} / \mathrm{CuO}$ nanowires, which shows that this material presents potential characteristics to be applied in the photodegradation of organic dyes [43]. On the other hand, the application of $\mathrm{CuO}$ nanowires in the photodegradation of various dyes, such as methyl orange (MO), direct red 81 (DR) and victoria blue (VB), have been reported [31,39-42]. However, these photocatalysts have been obtained by solution chemistry in basic media or by anodization with an electrolytic medium of only $\mathrm{KOH}[31,39-41]$, and in no case has an electrolytic medium based on ethylene glycol together with fluoride ions been used [11,31,39-43]. The electrolytic medium benefits the morphological order of the anodized nanostructures due to the high viscosity of the solvent and the interference generated by the fluoride ions on the surface of the copper layer during anodization [13,31]. 


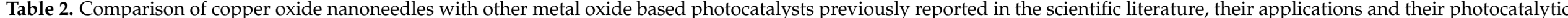
activity in dye degradation.

\begin{tabular}{|c|c|c|c|c|c|c|c|c|}
\hline Oxides & $\begin{array}{l}\text { Copper Oxide } \\
\text { Morphology }\end{array}$ & Copper Oxide Synthesis Type & $\begin{array}{l}\text { Composition of the } \\
\text { Electrolyte Solution }\end{array}$ & Application & Light Source & Degradation (\%) & Dye & Refs. \\
\hline $\begin{array}{c}\mathrm{Fe}_{2} \mathrm{O}_{3} / \mathrm{Cu}_{2} \mathrm{O} \\
\mathrm{Cu}_{2} \mathrm{O} / \mathrm{Ag} / \mathrm{TiO}_{2}\end{array}$ & \multirow{3}{*}{ Nanoparticles } & Hydrothermal & - & \multirow{6}{*}{ Photocatalysis } & \multirow{3}{*}{ Visible light } & $\begin{array}{l}90 \\
93\end{array}$ & $\begin{array}{l}\text { MB } \\
\text { MB }\end{array}$ & {$[60]$} \\
\hline $\mathrm{Cu}_{2} \mathrm{O} / \mathrm{Ag} / \mathrm{TiO}_{2}$ & & electrodeposition & $\mathrm{Cu}\left(\mathrm{NO}_{3}\right)_{2}+\underset{\text { acid }}{\mathrm{NaOH}}+$ lactic & & & 98 & $\mathrm{MB}$ & [62] \\
\hline $\begin{array}{c}\mathrm{Cu}_{2} \mathrm{O} / \mathrm{Ag} / \mathrm{TiO}_{2} / \mathrm{NFs} \text { PAN } \\
\mathrm{Cu}_{2} \mathrm{O} / \mathrm{NFs} \mathrm{PAN}\end{array}$ & & Electrospinning & & & & $\begin{array}{l}99 \\
60\end{array}$ & $\begin{array}{l}\mathrm{MB} \\
\mathrm{MB}\end{array}$ & {$[63]$} \\
\hline $\begin{array}{c}{\mathrm{P} 25-\mathrm{TiO}_{2}} \\
\text { (commercial standard) }\end{array}$ & \multirow{9}{*}{ Nanoneedles } & - & - & & \multirow[t]{2}{*}{ UV light } & 81 & MB & {$[43]$} \\
\hline $\mathrm{CuO}$ & & Solution chemistry in basic media & & & & 95 & DR and VB & [42] \\
\hline $\mathrm{Cu}_{2} \mathrm{O} / \mathrm{CuO}$ & & Chemical-thermal oxidation & & & Visible light & 80 & MB & [11] \\
\hline $\mathrm{CuO}$ & & $\begin{array}{l}\text { Anodization and } \\
\text { thermal treatment }\end{array}$ & $\mathrm{KOH}$ & \multirow[t]{2}{*}{ Anticorrosive surface } & \multirow[t]{2}{*}{ 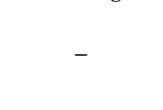 } & \multirow{2}{*}{-} & \multirow{2}{*}{-} & [39] \\
\hline $\mathrm{CuO}$ & & $\begin{array}{l}\text { Anodization and } \\
\text { thermal treatment }\end{array}$ & $\mathrm{KOH}$ & & & & & [31] \\
\hline $\begin{array}{l}\mathrm{Cu}_{2} \mathrm{O} \\
\mathrm{CuO}\end{array}$ & & \multirow{4}{*}{ Anodization } & $\begin{array}{l}\mathrm{KOH} \\
\mathrm{KOH}\end{array}$ & \multirow{4}{*}{ Photocatalisis } & \multirow{4}{*}{$\begin{array}{l}\text { Visible light } \\
\text { Sunlight }\end{array}$} & 93 & MO & $\begin{array}{l}{[40]} \\
{[41]}\end{array}$ \\
\hline $\mathrm{Cu}_{2} \mathrm{O} / \mathrm{CuO}$ & & & $\begin{array}{c}\mathrm{KOH}+10 \% \mathrm{H}_{2} \mathrm{O}+\mathrm{NH}_{4} \mathrm{~F}+ \\
\text { ethylene glycol }\end{array}$ & & & 88 & MB & This study \\
\hline $\mathrm{Cu}_{2} \mathrm{O} / \mathrm{CuO}$ & & & $\begin{array}{c}\mathrm{NaOH}+5 \% \mathrm{H}_{2} \mathrm{O}+\mathrm{NH}_{4} \mathrm{~F}+ \\
\text { ethylene glycol }\end{array}$ & & & 82 & $\mathrm{MB}$ & This study \\
\hline $\mathrm{Cu}_{2} \mathrm{O}$ & & & $\begin{array}{c}\mathrm{NaOH}+1 \% \mathrm{H}_{2} \mathrm{O}+\mathrm{NH}_{4} \mathrm{~F}+ \\
\text { ethylene glycol }\end{array}$ & & & 74 & MB & This study \\
\hline
\end{tabular}




\section{Conclusions}

Based on the results obtained in this research, we conclude that it is possible to synthesize $\mathrm{CuO}$ and/or $\mathrm{Cu}_{2} \mathrm{O}$ nanostructures (nanoneedles) using a very simple, one-step and low-cost method. The anodization of copper electrodes in a hydroxyl containing aqueous electrolytic medium, unlike other known methods for the formation of $\mathrm{CuO}$ or $\mathrm{Cu}_{2} \mathrm{O}$ nanostructures, does not require special electrolytes, chemicals or surfactants. The chemical characterization of the samples showed that nanowires of $\mathrm{Cu}_{2} \mathrm{O}$ or $\mathrm{CuO} / \mathrm{Cu}_{2} \mathrm{O}$ are obtained depending on the conditions of synthesis carried out; in addition, it was determined that nanowires are up to $1-2 \mu \mathrm{m}$ in length. In the photocatalytic degradation of the methylene blue dye $(\mathrm{MB})$ in the presence of the prepared copper oxide nanostructures, an $88 \%$ degradation of $\mathrm{MB}$ was obtained for the optimal morphologies. The photocatalytic activity of the material continues to show a high rate of degradation after five cycles of photodegradation, demonstrating the high stability of copper oxide nanostructures over time and the fundamental characteristics of reusable materials. These results are promising for the application of these types of nanostructured copper oxide films for designing new electronic devices with an easy-to-obtain and non-toxic photocatalyst for the photodegradation of organic molecules, such methylene blue dye.

Author Contributions: Conceptualization, A.T.; methodology, software, A.B.; validation, R.M.-T. and D.P.O.; formal analysis, M.F.; investigation, D.P.O.; resources, J.S.; data curation, J.S.; writingoriginal draft preparation, O.E.L.P.; writing-review and editing, C.Z. and D.P.O.; visualization, C.Z.; supervision, G.d.C.P.; project administration, funding acquisition, D.P.O. All authors have read and agreed to the published version of the manuscript.

Funding: The authors are grateful for support from the PAI77200065 project and Fondecyt 1191336 and the financial assistance by the fund Scientific and Technological Equipment, year 2019 code LE19-01, Universidad Tecnológica Metropolitana (UTEM). Microscopy facilities at LAMARX, FAMAFUNC/CONICET, Sistema Nacional de Microscopía-MINCyT, are gratefully acknowledged. RAMAN equipment at LANN, INFIQC-UNC/CONICET. OLP thanks the financial support from Project PUE-2017 CONICET \#22920170100092, PICT2019-2545 and SECYT-UNC.

Institutional Review Board Statement: Not applicable.

Informed Consent Statement: Not applicable.

Data Availability Statement: Data available on request.

Conflicts of Interest: The authors declare no conflict of interest.

\section{References}

1. Boulett, A.; Pizarro, G.; Martín-Trasanco, R.; Sánchez, J.; Tasca, F.; Linarez, O.; Tello, A.; Oyarzún, D.P. Electrodeposition of Cu글 nanostructures with improved semiconductor properties. Cogent Eng. 2021, 8, 1875534. [CrossRef]

2. Wong, M.H.; Berenov, A.; Qi, X.; Kappers, M.J.; Barber, Z.H.; Illy, B.; Lockman, Z.; Ryan, M.P.; MacManus-Driscoll, J.L. Electrochemical growth of ZnO nano-rods on polycrystalline Zn foil. Nanotechnology 2003, 14, 968-973. [CrossRef]

3. Gao, P.; Wang, Z.L. Self-assembled nanowire-nanoribbon junction arrays of ZnO. J. Phys. Chem. B 2002, 106, 12653-12658. [CrossRef]

4. Roy, S.; Basu, S. Improved zinc oxide film for gas sensor applications. Bull. Mater. Sci. 2002, 25, 513-515. [CrossRef]

5. Sumida, T.; Wada, Y.; Kitamura, T.; Yanagida, S. Macroporous ZnO films electrochemically prepared by templating of opal films. Chem. Lett. 2001, 30, 38-39. [CrossRef]

6. Holland, B.T.; Blanford, C.F.; Stein, A. Synthesis of macroporous minerals with highly ordered three-dimensional arrays of spheroidal voids. Science 1998, 281, 538-540. [CrossRef] [PubMed]

7. Macak, J.M.; Tsuchiya, H.; Ghicov, A.; Yasuda, K.; Hahn, R.; Bauer, S.; Schmuki, P. TiO 2 nanotubes: Selforganized electrochemical formation, properties and applications. Curr. Opin. Solid State Mater. Sci. 2007, 11, 3-18. [CrossRef]

8. Allam, N.K.; Grimes, C.A. Effect of rapid infrared annealing on the photoelectrochemical properties of anodically fabricated $\mathrm{TiO}_{2}$ nanotube arrays. J. Phys. Chem. C 2009, 113, 7996-7999. [CrossRef]

9. Diaz, J.J.; Fryauf, D.M.; Cormia, R.D.; Zhang, M.M.; Samuels, K.; Stanley, R.; Kobayashi, N.P. Reflectometry-ellipsometry reveals thickness, growth rate, and phase composition in oxidation of copper. ACS Appl. Mater. Interfaces 2016, 8, 22337-22344. [CrossRef]

10. Aiswarya, A.S.; Biju, V. Nanostructured CuO: Facile synthesis, optical absorption and defect dependent electrical conductivity. Mater. Sci. Semicond. Process. 2017, 68, 38-47. [CrossRef]

11. Bayat, F.; Sheibani, S. Enhancement of photocatalytic activity of $\mathrm{CuO}-\mathrm{Cu}_{2} \mathrm{O}$ heterostructures through the controlled content of $\mathrm{Cu}_{2}$ O. Mater. Res. Bull. 2021, 145, 111561. [CrossRef] 
12. Musselman, K.P.; Wisnet, A.; Iza, D.C.; Hesse, H.C.; Scheu, C.; MacManus-Driscoll, J.L.; Schmidt-Mende, L. Strong efficiency improvements in ultra-low-cost inorganic nanowire solar cells. Adv. Energy Mater. 2010, 22, E254-E258. [CrossRef]

13. Tello, A.; Boulett, A.; Sánchez, J.; Pizarro, G.; Soto, C.; Linarez, O.; Sanhueza, R.; Oyarzún, D.P. An unexplored strategy for synthesis of $\mathrm{ZnO}$ nanowire films by electrochemical anodization using an organic-based electrolyte. Morphological and optical properties characterization. Chem. Phys. Lett. 2021, 788, 138825. [CrossRef]

14. Jeong, D.; Lee, J.; Hong, H.; Choi, D.; Cho, J.W.; Kim, S.K.; Nam, Y. Absorption mechanism and performance characterization of $\mathrm{CuO}$ nanostructured absorbers. Sol. Energy Mater. Sol. Cells 2017, 169, 270-279. [CrossRef]

15. Hara, M.; Kondo, T.; Komoda, M.; Ikeda, S.; Kondo, J.N.; Domen, K.; Michikazu, H.; Shinohara, K.; Tanaka, A. Cu 2 O as a photocatalyst for overall water splitting under visible light irradiation. Chem. Commun. 1998, 3, 357-358. [CrossRef]

16. De Jongh, P.E.; Vanmaekelbergh, D.; Kelly, J.J. Cu $2 \mathrm{O}$ : A catalyst for the photochemical decomposition of water. Chem. Commun. 1999, 12, 1069-1070. [CrossRef]

17. Erné, B.; Vanmaekelbergh, D.; Kelly, J. Porous etching: A means to enhance the photoresponse of indirect semiconductors. Adv. Mater. 1995, 7, 739-742. [CrossRef]

18. Van de Lagemaat, J.; Plakman, M.; Vanmaekelbergh, D.; Kelly, J. Enhancement of the light-to-current conversion efficiency in an $\mathrm{n}-\mathrm{SiC} /$ solution diode by porous etching. Appl. Phys. Lett. 1996, 69, 2246-2248. [CrossRef]

19. Rakhshani, A. Preparation, characteristics and photovoltaic properties of cuprous oxide a review. Solid State Electron. 1986, 29, 7-17. [CrossRef]

20. Rai, B. $\mathrm{Cu}_{2} \mathrm{O}$ solar cells: A review. Sol. Cells 1988, 25, 265-272. [CrossRef]

21. Martin, C. Nanomaterials: A membrane-based synthetic approach. Science 1994, 266, 1961-1966. [CrossRef]

22. Sapp, S.; Lakshimi, B.; Martin, C. Template synthesis of bismuth telluride nanowires. Adv. Mater. 1999, 11, 402-404. [CrossRef]

23. Tan, Y.; Xue, X.; Peng, Q.; Zhao, H.; Wang, T.; Li, Y. Controllable fabrication and electrical performance of single crystalline $\mathrm{Cu}_{2} \mathrm{O}$ nanowires with high aspect ratios. Nano Lett. 2007, 7, 3723-3728. [CrossRef]

24. Zhang, H.; Zhang, X.; Li, H.; Qu, Z.; Fan, S.; Ji, M. Hierarchical growth of $\mathrm{Cu}_{2} \mathrm{O}$ double tower-tip-like nanostructures in water/oil microemulsion. Cryst. Growth Des. 2007, 7, 820-824. [CrossRef]

25. McShane, C.; Choi, K.S. Photocurrent enhancement of n-type $\mathrm{Cu}_{2} \mathrm{O}$ electrodes achieved by controlling dendritic branching growth. J. Am. Chem. Soc. 2009, 131, 2561-2569. [CrossRef] [PubMed]

26. Allam, N.; Grimes, C. Effect of cathode material on the morphology and photoelectrochemical properties of vertically oriented $\mathrm{TiO}_{2}$ nanotube array. Sol. Energy Mater. Sol. Cells 2008, 92, 1468-1475. [CrossRef]

27. Han, J.; Fan, F.; Xu, C.; Lin, S.; Wei, M.; Duan, X.; Wang, Z. ZnO nanotube-based dye-sensitized solar cell and its application in self-powered devices. Nanotechnology 2010, 21, 405203. [CrossRef]

28. Allam, N.; Grimes, C. Formation of vertically oriented $\mathrm{TiO}_{2}$ nanotube arrays using a fluoride free $\mathrm{HCl}$ aqueous electrolyte. J. Phys. Chem. C 2007, 111, 13028-13032. [CrossRef]

29. Allam, N.; Feng, X.; Grimes, C. Self-assembled fabrication of vertically oriented $\mathrm{Ta}_{2} \mathrm{O}_{5}$ nanotube arrays, and membranes thereof, by one-step tantalum anodization. Chem. Mater. 2008, 20, 6477-6481. [CrossRef]

30. Allam, N.; El-Sayed, M. Photoelectrochemical water oxidation characteristics of anodically fabricated $\mathrm{TiO}_{2}$ nanotube arrays: Structural and optical properties. J. Phys. Chem. C 2010, 114, 12024-12029. [CrossRef]

31. Wu, X.; Bai, H.; Zhang, J.; Chen, F.; Shi, G. Copper hydroxide nanoneedle and nanotube arrays fabricated by anodization of copper. J. Phys. Chem. B 2005, 109, 22836-22842. [CrossRef]

32. Allam, N.K.; Shankar, K.; Grimes, C.A. Photoelectrochemical and water photoelectrolysis properties of ordered TiO 2 nanotubes fabricated by tianodization in fluoride-free $\mathrm{HCl}$ electrolytes. J. Mater. Chem. 2008, 18, 2341-2348. [CrossRef]

33. Allam, N.K.; Alamgir, F.; El-Sayed, M.A. Enhanced photoassisted water electrolysis using vertically oriented anodically fabricated Ti-Nb-Zr-O mixed oxide nanotube arrays. ACS Nano 2010, 4, 5819-5826. [CrossRef]

34. Allam, N.K.; Shankar, K.; Grimes, C.A. A general method for the anodic formation of crystalline metal oxide nanotube arrays without the use of thermal annealing. Adv. Mater. 2008, 20, 3942-3946. [CrossRef]

35. Nanjo, H.; Hassan, F.M.; Venkatachalam, S.; Teshima, N.; Kawasaki, K.; Aizawa, T.; Aida, T.; Ebina, T. Fabrication of nanostructured titania on flexible substrate by electrochemical anodization. J. Power Sources 2010, 195, 5902-5908. [CrossRef]

36. Kandalkar, S.G.; Dhawale, D.S.; Kim, C.K.; Lokhande, C.D. Chemical synthesis of cobalt oxide thin film electrode for supercapacitor application. Synth. Met. 2010, 160, 1299-1302. [CrossRef]

37. Oyarzún, D.P.; López, M.; Ramos, W.; Linarez, O.; Sánchez, J.; Pizarro, G.; Acosta, G.; Flores, M.; Arratia-Perez, R. Nanostructuring of anodic copper oxides in fluoride-containing ethylene glycol media. J. Electroanal. Chem. 2017, 807, 181-186. [CrossRef]

38. Stepniowski, W.; Misiolk, W. Review of fabrication methods, physical properties, and applications of nanostructured copper oxides formed via electrochemical oxidation. Nanomaterials 2018, 8, 379. [CrossRef]

39. Xiao, F.; Yuan, S.; Liang, B.; Li, G.; Pehkoen, S.; Zhang, T. Superhydrophobic CuO nanoneedle-covered copper surfaces for anticorrosion. J. Mater. Chem. A 2015, 3, 4374-4388. [CrossRef]

40. Allam, N.; Grimes, C. Electrochemical fabrication of complex copper oxide nanoarchitectures via copper anodization in aqueous and non-aqueous electrolytes. Mater. Lett. 2011, 65, 1949-1955. [CrossRef]

41. Momeni, M.; Ghayeb, Y.; Menati, M. Facile and green synthesis of $\mathrm{CuO}$ nanoneedles with high photo catalytic activity. J. Mater. Sci. Mater. Electron. 2016, 27, 9454-9460. [CrossRef] 
42. Singh, V.; Bansal, P. Fabrication and characterization of needle shaped $\mathrm{CuO}$ nanoparticles and their application as photocatalyst for degradation of organic pollutants. Mater. Lett. 2020, 261, 126929. [CrossRef]

43. Tichapondwa, S.; Newman, J.; Kubheka, O. Effect of $\mathrm{TiO}_{2}$ phase on the photocatalytic degradation of methylene blue dye. Phys. Chem. Earth 2020, 118-119, 102900. [CrossRef]

44. Mittal, H.; Alhassan, S.M.; Ray, S.S. Efficient organic dye removal from wastewater by magnetic carbonaceous adsorbent prepared from corn starch. J. Environ. Chem. Eng. 2018, 6, 7119-7131. [CrossRef]

45. Oyarce, E.; Pizarro, G.; Oyarzún, D.P.; Martín-Trasanco, R.; Sánchez, J. Adsorption of methylene blue in aqueous solution using hydrogels based on T 2-hydroxyethyl methacrylate copolymerized with itaconic acid or acrylic acid. Mater. Today Commun. 2020, 25, 101324. [CrossRef]

46. Katheresan, V.; Kansedo, J.; Lau, S.Y. Efficiency of various recent wastewater dye removal methods: A review. J. Environ. Chem. Eng. 2018, 6, 4676-4697. [CrossRef]

47. Huang, C.; Lai, C.; Zhang, C.; Zeng, G.; Huang, D.; Cheng, M.; Hu, L.; Xiong, W.; Chen, M.; Wang, J.; et al. Semiconductor/boron nitride composites: Synthesis, properties, and photocatalysis applications. Appl. Catal. B Environ. 2018, 238, 6-18. [CrossRef]

48. Flores, M.; Donoso, S.; Ortiz, M.; Fernández, H. Alkanethiol self-assembled monolayer on copper polycrystalline thin films: Influence on the resistivity. Mater. Chem. Phys. 2018, 208, 97. [CrossRef]

49. Cabello, G.; Lillo, L.; Caro, C.; Buono-Cuore, B.; Chornik, B.; Flores, M.; Carrasco, C.; Rodriguez, C. Photochemical synthesis of $\mathrm{AZrO}_{3-\mathrm{X}}$ thin films (A=Ba, Ca and Sr) and their characterization. Ceram. Int. 2014, 40, 7761. [CrossRef]

50. Benito, N.; Flores, M. Evidence of Mixed Oxide Formation on the $\mathrm{Cu} / \mathrm{SiO}_{2}$ Interface. J. Phys. Chem. 2017, 121, 18771. [CrossRef]

51. Oyarzún, D.P.; Córdova, R.; Linarez, O.; Muñoz, E.; Henríquez, R.; López, M.; Gomez, H. Morphological, electrochemical and photoelectrochemical characterization of nanotubular $\mathrm{TiO}_{2}$ synthetized electrochemically from different electrolytes. J. Solid State Electrochem. 2011, 15, 2265-2275. [CrossRef]

52. Mayer, S.T.; Muller, R.H. An in situ raman spectroscopy study of the anodic oxidation of copper in alkaline media. J. Electrochem. Soc. 1992, 139, 426-434. [CrossRef]

53. Ivanda, M.; Waasmaier, D.; Endriss, A.; Ihringer, J.; Kirfel, A.; Kiefer, W. Low-temperature anomalies of cuprite observed by Raman spectroscopy and x-ray powder diffraction. J. Raman Spectrosc. 1997, 28, 487-493. [CrossRef]

54. Platzman, I.; Brener, R.; Haick, H.; Tannenbaum, R. Oxidation of polycrystalline copper thin films at ambient conditions. J. Phys. Chem. C 2008, 112, 1101-1108. [CrossRef]

55. Biesinger, M. Advanced analysis of copper X-ray photoelectron spectra. Surf. Interface Anal. 2017, 49, 1325-1334. [CrossRef]

56. Oyarzún, D.P.; Broens, M.; Linarez, O.; López, M.; Islas, R.; Arratia-Perez, R. Simple and rapid one-step electrochemical synthesis of nanogranular $\mathrm{Cu}_{2} \mathrm{O}$ films. Chem. Select 2018, 3, 8610-8614. [CrossRef]

57. Scuderi, V.; Amiard, G.; Boninelli, S.; Scalese, S.; Miritello, M.; Sberna, P.; Impellizzeri, G.; Privitera, V. Photocatalytic activity of $\mathrm{CuO}$ and $\mathrm{Cu}_{2} \mathrm{O}$ nanowires. Mater. Sci. Semicond. Process. 2016, 42, 89-93. [CrossRef]

58. Dariani, R.; Esmaeili, A.; Mortezaali, A.; Dehghanpour, H. Photocatalytic reaction and degradation of methylene blue on $\mathrm{TiO}_{2}$ nano-sized particles. Optik 2016, 127, 7143-7154. [CrossRef]

59. Zhang, Z.; Yu, Y.; Wang, P. Hierarchical top-porous/bottom-tubular $\mathrm{TiO}_{2}$ nanostructures decorated with Pd nanoparticles for efficient photoelectrocatalytic decomposition of synergistic pollutants. ACS Appl. Mater. Interfaces 2012, 4, 900-996. [CrossRef] [PubMed]

60. Norouzi, A.; Nezamzadeh-Ejhieh, A. $\alpha-\mathrm{Fe}_{2} \mathrm{O}_{3} / \mathrm{Cu}_{2} \mathrm{O}$ heterostructure: Brief characterization and kinetic aspect of degradation of methylene blue. Phys. Rev. B Condens. Matter 2020, 599, 412422. [CrossRef]

61. Wang, Q.; Liu, Z.; Zhang, S.; Cui, Y.; Gao, S.; Wang, Y. Hydrothermal deposition of $\mathrm{Cu}_{2} \mathrm{O}-\mathrm{Ag}$ nanoparticles co-sensitized TiO 2 nanotube arrays and their enhanced photoelectrochemical performance. Sep. Purif. Technol. 2019, 211, 866-872. [CrossRef]

62. Duan, J.; Zhao, H.; Zhang, Z.; Wang, W. The Z-scheme heterojunction between $\mathrm{TiO}_{2}$ nanotubes and $\mathrm{Cu}_{2} \mathrm{O}$ nanoparticles mediated by Ag nanoparticles for enhanced photocatalytic stability and activity under visible light. Ceram. Int. 2018, 44, 22748-22759. [CrossRef]

63. Li, X.; Raza, S.; Liu, C. Directly electrospinning synthesized Z-scheme heterojunction $\mathrm{TiO}_{2} @ \mathrm{Ag}_{0} \mathrm{Cu}_{2} \mathrm{O}$ nanofibers with enhanced photocatalytic degradation activity under solar light irradiation. J. Environ. Chem. Eng. 2021, 9, 106133. [CrossRef] 